\title{
Yoga Inner Beauty as a Lifestyle Women in Ghanta Yoga Asram Kertalangu Village, East Denpasar
}

\author{
Ni Nengah Karuniati \\ Universitas Hindu Indonesia, Denpasar, Indonesia \\ Corresponding author email: karuniatinengah@gmail.com
}

\author{
I Ketut Suda \\ Universitas Hindu Indonesia, Denpasar, Indonesia \\ Email: suda@unhi.ac.id \\ I Wayan Budi Utama \\ Universitas Hindu Indonesia, Denpasar, Indonesia \\ Email: budiutama904@gmail.com
}

\begin{abstract}
Balinese women today want to feel more beautiful and acceptable in society. Therefore, women do yoga inner beauty which makes practitioners healthy, someone's beauty will shine clearly, and lead to a healthy and harmonious life. In addition, women also need their self-actualization in the form of a career path for them. This study uses a qualitative-analytic method with an interactive approach. The results obtained are as follows. First, the reason why women choose inner beauty yoga at the Ghanta Yoga Asram Denpasar is because women believe that doing inner beauty yoga and meditation every day can radiate inner beauty energy, making the body healthy, beautiful, and youthful. Second, the process of applying inner beauty yoga for women at the Ghanta Yoga Asram Denpasar is starting from socialization, initiation process, worship, the yoga implementation process is carried out from level I to level $V$ and level of purification. Third, the implication of the application of yoga inner beauty for women at the Ghanta Yoga Asram Denpasar is that after participating in yoga, women become more patient, healthier, more beautiful, more harmonious, and more sincere in accepting the situation, and full of confidence. Keywords---body healthy, inner beauty, lifestyle women, meditation, yoga
\end{abstract}

\section{Introduction}

The teaching of yoga is sacred teaching which is a teaching of release that aims to connect oneself and be united with God for Hindus through the stages of astang yoga. However, nowadays the yoga that is practiced is only the asanas and pranayama stages or often referred to as yoga asanas (Wirawan, 2018). Maharsi Patanjali teaches eight stages of yoga known as astang yoga which consists of yama, nyama, asana, pranayama, pratyahara, dharana, dhyana, and samadhi. Yoga comes from the Sanskrit "yuj" which means union with the creator. In other words, yoga is a human effort to connect with God Almighty. Thus, the main requirement for a prospective yoga practitioner is belief and belief in the existence of God.

Furthermore, yoga, which was originally a personal spiritual ritual practice, has become an exercise for the body, soul, and mind. Yoga, like other sports, can be commercialized and sold at high prices. That is why there are lots of yoga classes and fees, even though originally it is an independent activity, yoga cannot compete. Some types of yoga offer separate classes including instructors having different types of yoga (Adnyani, 2017; Chaedar, 2002; Ambara, 2014; Bandura, 1990; Handayani, 2013).

Yoga is a way or way of life to control the mind in which a person concentrates the whole mind to control the five senses and the body as a whole. Therefore, a yoga practitioner must also have a high moral and discipline basis. In this day and age, many women regularly do yoga. This can not be separated from women experiencing psychological 
stress more easily to eliminate the problems that exist in women is through yoga, namely yoga inner beauty which is believed and believed to be able to reduce the problem compared to men (Andriani, 2011; Assael, 1992; Atmadja, 2009; Atmadja \& Atmadja, 2014).

The inner beauty yoga at the Ghanta Yoga Asram is suitable for women because the yoga asanas are modified such as the dance of the Goddess Ganga, soft, aesthetic, artistic, which makes the appearance very attractive to others people. Yoga's inner beauty will also make them more beautiful. The beauty referred to here is the beauty that has the taksu of beauty, namely the beauty that emanates from within (inner beauty) which makes a person healthy and beautiful, has a good personality, is flexible, graceful, charming, attractive, and confident, and is in harmony with achieving harmony within himself. himself (Putri \& Darwis, 2015). From this concept, yoga inner beauty is a yoga specifically performed by women with modified yoga asanas in the form of an aesthetic Dewi Ganga dance, which then grows taksu mentik for a woman which makes the woman confident, attractive, and attractive. looks beautiful, and exudes a feminine aura for the practitioner.

According to Kotler (in Kanserina et al., 2015), lifestyle is a person's lifestyle in the world which is expressed in his activities, interests, and opinions, in the sense that in general a person's lifestyle can be seen from the routine activities he does, what they think of everything around him and how much he cares about it and also what he thinks about himself and the outside world. Lifestyle can come from the desire to create its characteristics, or it can also come from other people. The influence of others can come from suggestions, the fit that other people see, the desire to be someone else, or so on. Lifestyle is habits that arise from within humans that form patterns that make them feel happy, want to do, and don't feel burdened by doing it which is a characteristic of that person. This lifestyle is influenced by various behaviors that exist in society. This is done for acceptance in the environment (Barlow, 1985; Berg \& Lune, 2007; Bungin, 2003; Cleopatra, 2015; Artana et al., 2019).

In this modern era, many women do their work not only around the household, but also carry out social activities outside the household. For this reason, they need to actualize themselves so that they can be accepted in society. One of their self-actualizations is beauty. Beauty will bring out the feminine side of a woman. This is inseparable from the culture of society about women being beautiful to be able to increase the prestige of the family. Putri (2022), says that feminist criticism states that the idea of beauty is a form of male domination. It is men who want the criteria of beauty and make them a guide for women. This is emphasized by Prabasmoro (2004), who argues that the discourse on women's beauty and femininity cannot be separated from the construction of a patriarchal culture that gives men the power to give recognition to their femininity.

\section{Research Method}

This research method uses interpretive qualitative research methods because it is in the form of descriptive data in the form of words and expressions including actions that can be observed during the research process. The research was conducted based on the results of observations and observations. The data used are primary in the form of interviews with informants where the selection and number of informants in qualitative research is not determined in terms of numbers, but prioritizes efforts to obtain as much information as possible with deep accuracy from various sources and secondary data in the form of documents and records. from the research site.

\section{Research Results}

\section{Reasons women follow yoga inner beauty}

The reason for women to follow inner beauty yoga is that philosophically, women follow inner beauty yoga, namely by doing the Rejang Taksu Buana dance where inner beauty yoga which is strongly believed by women is a dance created by Ratu Guru and students, namely the Rejang Taksu Buana Dance. to worship Ida Sang Hyang Tri Adi Taksu or Ida Sang Hyang Widhi which means that by doing yoga inner beauty can cure disease, physically and mentally healthy. In addition, it can also exude taksu of beauty, flexibility, elegance, harmony, and a noble personality. In particular, they also get taksu swagina, which means that what is done is indeed me-taksu. Women choose yoga inner beauty, aiming to activate all the elements and elements that exist throughout the body. All elements are interrelated with each other that shackles humans in their lives. By doing yoga or meditation on inner beauty, women feel they have the use and function to activate the energy in themselves and the whole body, which at first did not realize there was an energy power within them (Davidow \& Uttal, 1989; Udayana, 2019; Dewi et al., 2017; Dinata, 2015). 
The ideological reason is with yoga inner beauty to get taksu swagina. Any business that is occupied and believed in, is successful and can also radiate beauty and health. This means that by the following yoga as a lifestyle, a change in attitude and behavior can occur, namely smiling and patient. This is also reinforced by women who follow inner beauty yoga to want to look more beautiful and fashionable so that women also do facial therapy which can be done at the Ghanta Yoga Asram and women who participate in yoga inner beauty buy pearl bracelets for accessories to beautify their bodies to make them look beautiful. and beautiful. With the use of these beauty tools, the Ghanta Yoga Asram has commercial value. This is as said by Geoffrey (in Artana, 2019), that spiritual teacher assure students, purchased items such as pearl bracelets, jade pendants, green jade, and beauty tools that are passed down have functions according to their use.

Psychological reasons, namely for women, yoga inner beauty is a basic need or psychological need that must be done in a disciplined and routine every day. According to him, the inner beauty yoga he follows is a lifestyle. Psychologically, women follow inner beauty yoga in addition to health as well as for self beauty. If you are healthy, you will look beautiful, beautiful, and charming. Outward physical beauty is a gift. But many people say that true beauty is an inner event and outer beauty is only an appearance of inner beauty. Inner beauty is timeless. The purpose of yoga's inner beauty is not because of physical beauty but to experience inner happiness. Happiness shines through the eyes, appearance, attitude, and behavior towards others. All of which makes it interesting. An unhappy person rarely has the same charm as someone dangerous and passionate (Dittmann \& Freedman, 2009; Echols \& Shadily, 2019; Elizabeth, 2007).

The reason for health is that those who regularly do yoga or inner beauty meditation performed by women have a healthier state. Happier and more efficient. Human health is primarily influenced by the mind. Maharsi Patanjali called the mind the citta. He then said: "The mind is the main cause of suffering or happiness. Only people who can control or use their minds well, neatly, and truly can live peacefully (Yogasutra, in Wirawan et al., 2020). In addition, to beautify oneself and change appearance, namely in the sense of how the value and meaning of life, health, beauty, beauty, self-confidence, self-actualization, and self-existence are obtained by following yoga or inner beauty meditation. To be able to look beautiful, charming, physically and mentally healthy, modern, and elegant, the management of the hostel has provided a comfortable meditation place away from crowded settlements, so that yoga participants get a sense of comfort and peace. Many women are interested in participating in inner beauty yoga after receiving information from their friends who have felt that following yoga and meditation makes them healthier and more confident. beauty is not only limited to physical exercises (body) but also meditation with rich exercises for the mind and soul so that it can be said that yoga is a method to achieve the best and most complete health of the body, mind, and soul (Herlyana, 2014; Esterberg, 2002; Fandhira et al., 2017; Hamka, 2016).

The reason for free time is that in today's era of globalization, people who are busy with their work rarely have time to rest their bodies even if only for a moment. The body needs adequate rest, according to the activities taken. Therefore, in order to balance his busy life with rest, we need to know and learn yoga or meditation. Yoga can help us rest the body in a hectic schedule, which causes no time for special rest (Darmayasa \& Sukra, 2013). The inner beauty yoga at Asram Ghanta Yoga is specifically for women and is loved by women. Given that women in modern times have quite a lot of busyness, such as working in an office, having a business, and being a housewife, it is very difficult to make time. Many women are very interested in participating in inner beauty yoga at the Ghanta Yoga Asram, because yoga only starts in the afternoon around 19.00 WITA. For women who work, they can take the time to follow inner beauty yoga after finishing work. Yoga or meditation on inner beauty can make women healthy, flexible, graceful, beautiful, elegant, smiling, radiant, fresh, and beautiful. For women, yoga is a lifestyle so yoga becomes an obligation in life. Career women who have quite a busy schedule as well as public figures to maintain stamina, body fitness, and can radiate beauty intact need to take the time to participate in yoga. Inner beauty is the art of body and breathing which is one of the emotional training techniques in controlling anxiety. Inner beauty yoga is also useful as a regulation between mind and body harmony. In addition, inner beauty yoga has goals such as improving mental well-being and increasing emotional balance (Muhammad \& Abdushomad, 2002; Hawari, 2013; Hendariningrum \& Susilo, 2014).

\section{The process of implementing yoga inner beauty as a women's lifestyle}

The process of implementing inner beauty yoga begins with socialization by the manager of the Ghanta Yoga Asram where the instructors at the Ghanta Yoga Asram are intended to attract inner beauty yoga participants to join the yoga practice at the hostel. This socialization process is carried out through various media such as newspapers, television, websites, Facebook, and WhatsApp. Apart from social media, activities to attract potential yoga participants are also carried out by distributing invitations directly to women. Women who participated in the 
socialization were given an understanding of Ghanta energy, namely energy that can radiate God's miracles to be able to radiate taksu potential in a woman. Ghanta Yoga practitioners hone Ghanta energy to be able to radiate the taksu of their profession. Every woman has potential in herself and by honing it, taksu can be emitted and make it easier for someone to live life. From this socialization, it was found that inner beauty yoga can improve personality and new life patterns, namely learning to be patient, sincere, and confident. This is reinforced by the social learning theory of Albert Bandura which views human behavior as not merely a reflex, automatically from stimulus and response, but also as a result of reactions that arise as a result of the interaction between the environment and the human cognitive scheme itself. After listening to the socialization in which the women responded that the inner beauty yoga could radiate taksu beauty and taksu swagina, then they felt interested in following it (Kaelan, 2005; Khotimah, 2009; Laksono, 2012; Miles \& Huberman, 1992).

The next process is the recruitment process where prospective participants have filled out a registration form and are immediately given a readable guidebook. The book contains about the existence of Asram Ghanta Yoga in general and yoga inner beauty in particular. The understanding given to the prospective participants of yoga inner beauty is that all the requirements must be completed by the participants in accordance with the provisions in the Ghanta Yoga Asram such as submitting forms and providing generous punia funds so that their status becomes a definitive student (You \& Ogawa, 2020; Lauche et al., 2017; Kakigi et al., 2005). This inner beauty yoga program which has been marketed throughout Bali through Ghanta Yoga Asram branches spread across several districts, namely Tabanan, Jembrana, Buleleng, and Karangasem as well as in Denpasar as the Ghanta Yoga Asram Center. Seeing these developments, in addition to having direct benefits for health and various desired specific goals. In the practice of inner beauty yoga which is followed by women, it does not change the initial grip on the true purpose of yoga itself.

For Nimtz (2000), the transition from feudalism which is a social system that gives great power to leaders or nobles to capitalism is a transition from need-driven production to production for profit. Seeing the phenomenon of the recruitment of yoga inner beauty participants about the existence of levies in the form of money is not a payment but is packaged with punia. As described by Piliang (2004), the expansion of the capitalist system into the world of education has created a condition where the logic of education and the logic of capitalism is linked. Conditions like this then make education into what he calls a capitalist machine, namely a machine to seek profit. Suardana's point of view, should be that any form and type should be carried out transparently, but there are still other hidden phenomena behind recruitment and initiation fees. If this is constructed, it will be possible to identify a phenomenon behind punia as a way to participate in inner beauty yoga training, namely a pragmatic attitude. This attitude shows that what is true is anything that shows itself as true by looking at the beneficial consequences or results. Meanwhile, Adriana sees that punia needs to be done to form sincerity. Thus, the implementation of meditation (yoga inner beauty) in yoga activates taksu of beauty which implies the formation of a complete human being, namely physically and spiritually and spiritually healthy which can radiate taksu of beauty from within the followers of Ghanta Yoga's inner beauty. From this, it can be seen that the Ghanta Yoga Asram is an exchange of money and services. The better Asram's marketing method or strategy through yoga inner beauty products is through socialization (understanding) to convince the socialization participants, the more people recruited, the more income will be (Newcombe, 2007; Rahima, 2006; Rahmaniyah, 2010; Saskara \& Maskie, 2012).

The next process is an initiation where initiation is the inauguration of students accepted at the Ghanta Yoga Asram who go through an initiation process, namely cleansing the minds and hearts of inner beauty yoga participants. Initiation is done at the place of worship. initiation is done by a Guru to students who are just starting to enter the first stage of learning or practicing yoga. To remove all impurities and negative elements that exist within oneself can be interpreted that initiation is self-purification. By following inner beauty yoga, there is a cultural shift among students, such as becoming more disciplined and more patient.

After the participants of yoga inner beauty have initiated, the next process is the process of embracing where the process of carrying out the embracing carried out by students, especially women before participating in the training (stages) of yoga inner beauty can be interpreted as self-cleaning, so that all dirt and disease both physically and mentally and eliminating the mala that is in the body of each student who participates in yoga inner beauty has different problems. This is in line with Aprilianti (2020), namely that women are more likely to be stressed because women tire more quickly. With melukat, it gives peace of mind, soul, and gives freshness to the body, after melukat is added with the belief that blessings will come down through melukat.

After this series of processes, the yoga participants begin the inner beauty yoga process where yoga meditation on inner beauty is a process in the practice of routine training at the Ghanta Yoga Asram Denpasar, namely by paying attention to guidelines or guidelines in order to provide clear and directed patterns. As for the guidance in doing inner beauty Ghanta meditation in stages, starting with the preparatory and preliminary phases. This phase includes 
outward and inward preparation so that there are no obstacles that cause physical and mental disturbances. This phase determines the comfort and tranquility of practicing. Several things need to be considered by a woman in the preparation phase, namely taking a shower when she wakes up in the morning. Light breakfast wearing comfortable clothes and practically no jewelry. Prepare a mat or mat for exercise and place it in a comfortable place. Praying together in the holy place of the Asram area with a perfect sitting posture and carried out according to each other's beliefs and beliefs. For students, before participating in inner beauty yoga, they are required to pray first at the sacred Gedong which is delivered by the Asram Administrator who has just entered the room to take part in the inner beauty yoga practice (Sastropoetro, 1986; Segara, 2020; Sengupta, 2012; Singer, 2015; Kumar \& Sumathi, 2017).

Students learn through the stages of practice where the yoga inner beauty level consists of level 1 to level 5 . At the initial level or level 1, yoga inner beauty participants find it difficult to sit in one posture for a very long time. However, students should not give up but remain persistent with the premeditation exercises. Unexpectedly the students felt that the meditation attitudes made it possible to sit down for a short time. At this stage, students will increasingly increase the duration of the implementation by half a minute every day. Even students with stiff bodies are finally able to sit in the padmasana posture. This is in line with the approach of social learning theory in the face of social and moral development processes, emphasizing the need for conditioning (response habituation) and imitation (imitation). According to Bandura et al. (1989), most human behavior is learned through imitation.

If the student has passed the yoga inner beauty at a level, then the yoga inner beauty can be continued at a higher level. At a high level, participants in yoga inner beauty feel that with perseverance and confidence there can be a change in behavior for the better which means that they have been able to accept the situation even though it is not yet fully understood. positive. At each level, an evaluation will be carried out where if the inner beauty yoga student is declared to have passed, the inner beauty yoga participant can advance to the next level. On the other hand, if students of yoga inner beauty are not able to reach the next level, it is advisable to do yoga inner beauty well. One of the reasons why participants in yoga inner beauty can't go up is because they feel lazy to do yoga inner beauty so they become undisciplined and disorganized in doing yoga inner beauty. Another reason is that there is a reward to go to the next level which inner beauty yoga participants cannot fulfill. Of course, this is related to the economic situation of each participant of yoga inner beauty. This indicates that there has been a willingness of the Asram authorities to obtain capital to continue the programs planned by the Asram. Thus, it can be proven what Derrida said in his deconstruction theory that there is a delayed meaning in a discourse (Artana, 2019). Even if there are material rewards in the form of money, this should be done by students as a form of student devotion to God. Punia does not know a lot of material, but the sincerity of students as members of a boarding community, students also have an obligation to care for, maintain, and ensure the sustainability of the hostel.

At a high level, namely at level 5, the participants of yoga inner beauty felt something different in themselves. After the participants of the yoga of inner beauty followed yoga of inner beauty (Level 1) until the last stage, namely Level 5, they felt that they had patience, harmony in the family. The taksu inner beauty radiates from within and the taksu swagina begins to be felt as stated by the yoga inner beauty participants. Women experience a change as a guide in life. To take part in the yoga training process, one must be able to concentrate well (Darmayasa \& Sukra, 2013). In accordance with the instructor's guidance, if you want to get maximum results, that is, believe in it, keep practicing. At the next level is the refining level where not all students who have finished following level 5 can continue. Several requirements must be met, among others: 1) a matter of time; 2) funds; 3) strong belief; 4) intention; and 5) a sense of sincerity. If all the requirements have been met, it means that you can proceed to level 6 , namely, pure meditation yoga, which is purification, which means that you have been accepted as a pure student, namely being able to do independent meditation by participating in meditation with Guru Nabe both in the Asram and at the Taksu Bukit Taman Teaching Temple.

At each stage of inner beauty yoga, every student at the Ghanta Yoga Asram is no exception, students who have been given briefing and stabilization as well as an understanding of how to learn and train themselves in meditation, which means that every student at the Ghanta Yoga Asram, both spiritually and spiritually, has been given an understanding in yoga training. inner beauty. The meaning contained in inner beauty yoga meditation is that yoga training requires discipline, belief, and sincerity. The hostel management not only selects yoga inner beauty participants but also women who have faith and have the necessary capital to fund money in the hostel. The hostel management also provides briefing in the form of insight along with strengthening skills in meditation and taksu swagina (life skills) for yoga participants. It can also be seen that a learning process for yoga inner beauty by imitating is in accordance with its objectives to achieve health and have better manners. The last training was given by Guru Nabe to find out that each pure student will get taksu swagina in his field according to the student. The purpose of learning yoga at the Ghanta Yoga Asram, Kertalangu Village, East Denpasar is to be able to radiate taksu 
inner beauty and taksu swagina because this is the most important thing in managing better family life (Saatcioglu, 2013; Cramer et al., 2017; Telles \& Desiraju, 1993; Paulson, 2008).

\section{Implications of implementing yoga inner beauty as a lifestyle among women}

The implication of the implementation of inner beauty yoga as a lifestyle on aspects of physical health is that women are required to be able to move according to a very dynamic pace of life. Every aspect of human life, including women's lives, becomes fast-paced, practical, especially for women who live in urban areas. Women are susceptible to various kinds of disease disorders due to consumption patterns, intensity, and heavy workloads that trigger highstress levels. For this reason, women choose inner beauty yoga after coming home from work as a form of health awareness, which can have positive implications for women whereby following regular and disciplined yoga practices, the body and mind will become healthy. The stress and anxiety that a person faces can be reduced by following inner beauty yoga and this activity have proven to be a practical and effective tool for promoting health and happiness. Those who regularly do inner beauty yoga are healthier, more flexible, happier, and more efficient. Related to inner beauty yoga practice at Ghanta Yoga Asram Denpasar, apart from being able to radiate taksu inner beauty or beauty, body health as the main factor in human life can also be maintained. This is because in the practice of yoga inner beauty is given exercise exercises that aim to relax the muscles in the body to form a slim body (slim body) and flexibility so that it can resemble the Rejang Taksu Buana dance, namely the Dewi Gangga dance, very beautiful and graceful (Dada \& Tolahunase, 2018; Neumark-Sztainer et al., 2018; Garfinkel \& Schumacher Jr, 2000).

The implication of yoga inner beauty as a women's lifestyle from a psychological aspect, namely Yoga inner beauty is a need for women to be able to look healthy, beautiful, for prestigious, and the thing that arises in women after participating in inner beauty yoga is the beauty of inner beauty. flexibility, and elegance in women who follow yoga. Beauty plays an important role for women, with a lifestyle as a symbol of the prestige of a certain class and can be fashionable which spreads through mass communication through social stratification boundaries, so that women who follow inner yoga regularly and discipline can have implications for self-confidence and can appear more confident and look more beautiful and attractive, which is the dream of every woman.

In the sociological aspect, participating in inner beauty yoga training shows that women socially have a function to reinforce their position in society. The motivation for looking ideal is wanting to get praise from the people around him. This is not only found among certain women but all people who consciously or unconsciously have motivation. Wearing appropriate and ethical clothing, full of smiles can convey a message to others that the woman after participating in inner beauty yoga has a different appearance. Women tend to prepare their appearance before coming to an event by visiting a beauty salon located in the Ghanta Yoga Asram environment which aims to beautify themselves by doing facial treatments such as makeup (make-up), neatly arranged hair (hairdo), nail care (manicure, pedicure), and other treatments that make you look more beautiful. Overall it is a way for women in the Asram to further strengthen and legitimize socially to show themselves as modern women. From this, it becomes a phenomenon that shows that there is a change in women's social attitudes after participating in inner beauty yoga. In the past, women rarely wanted to show themselves, but now it is commonplace and commonplace. Looks beautiful, elegant, flexible, and charismatic as a lifestyle or lifestyle of women which indicates there is progress in the level of life (Suamba, 2015; Suda, 2017; Sudiarta, 2006; Susanto, 2013; Wiasti, 2011).

The implication for the cultural aspect is that inner beauty yoga participants grow the ideas they get after doing inner beauty yoga where inner beauty yoga participants carry out activities related to culture and religion in the form of ceremonial tools such as canang and incense. With wider consumption of ritual facilities such as banten, the shift in the tradition of Balinese women in general and Denpasar women in particular, namely from the habit of making offerings in cooperation to the habit of buying banten. This is inseparable from the urban community who do not have time to make ceremonial tools because they are busy with work. For this reason, people also prefer to buy canang-making services. This phenomenon can be seen that cultural ideas on inner beauty yoga can provide sustenance for themselves and their families where inner beauty yoga participants can preserve and increase family income.

\section{Conclusion}

The reason why women choose inner beauty yoga at the Ghanta Yoga Asram Denpasar is to overcome their psychological and mental problems. Philosophically, yoga inner beauty is a rejang taksu buana dance that has the meaning of being able to cure disease, be physically and mentally healthy, and can channel inner beauty energy. 
Yoga inner beauty also makes women regularly do body therapy and use clothes that make women look fashionable and beautiful. Women who look beautiful and attractive will make someone more confident and increase their social status in society. In addition, yoga inner beauty is done regularly to make a woman calm and patient so that the body becomes healthier and happier. Because of the great benefits of inner beauty yoga and many women are busy because of their work and career, women also need to give special time or free time to do inner beauty yoga regularly which is usually done when finished doing their work. Yoga inner beauty is carried out through stages, namely socialization, recruitment, initiation, embracing, yoga inner beauty from level 1 to level 5, and level of purification. Each level is always evaluated and if students pass, they can move up to the next level. The implication of women doing inner beauty yoga as a lifestyle is that women look more beautiful, flexible, and radiant because they can radiate inner beauty taksu. In addition, women become more calm and patient so that problems that arise can be resolved. Another thing is to come up with ideas to earn income and improve the family's economy.

\section{Acknowledgments}

The author would like to thank Asram Ghanta Yoga and Postgraduate UNHI Denpasar.

\section{References}

Adnyani, N. W. S. (2017). Pengembangan Wisata Yoga Melalui Tren Wisata Babymoon di Ubud, Bali. Lilaprayata: Journal Of Tourism, 2(1), 81-88.

Ambara, J. (2014). Penerimaan Pemirsa Perempuan Terhadap Pesan Gaya Hidup Dalam Iklan-iklan Kopi Dengan Endorser Perempuan. Jurnal E-Komunikasi, 2(1).

Andriani, T. (2011). Media Massa dan Konstruksi Gaya Hidup Perempuan. Marwah: Jurnal Perempuan, Agama dan Jender, 10(2), 147-162.

Aprillianti, P. R. K. D. (2020). Pengaruh Melukat Terhadap Penurunan Stres (Doctoral dissertation, Politeknik Kesehatan Denpasar Jurusan Keperawatan).

Artana, I. W. (2020). Pertukaran Modal berbalut Bhakti Yoga.

Artana, I. W., Suda, I. K., \& Winaja, I. W. (2019). Achieving physical and spiritual happiness on bhakti yoga. International Journal of Linguistics, Literature and Culture, 5(4), 7-18. https://doi.org/10.21744/ijllc.v5n4.685

Assael, H. (1992). Consumer Behavior and Marketing Act.

Atmadja, N. B. (2009). Komodifikasi tubuh perempuan: joged" ngebor" Bali. Program Studi Magister dan Doktor, Kajian Budaya, Universitas Udayana.

Atmadja, N. B., \& Atmadja, A. T. (2014). Filsafat ilmu pengetahuan: perspektif proses dan produk. Pustaka Larasan.

Bandura, A. (1990). Some reflections on reflections. Psychological inquiry, 1(1), 101-105.

Bandura, A., Valentine, E. R., Nesdale, A. R., Farr, R., Goodnow, J. J., Lloyd, B., \& Duveen, G. (1989). Social cognition.

Barlow, D. L. (1985). Educational psychology: The teaching-learning process. Moody Press.

Berg, B. L., \& Lune, H. (2007). Chapter 11: An introduction to content analysis. Qualitative research methods for the social sciences, 238, 267.

Bungin, B. (2003). Metode Penelitian Kualitatif, Jakarta: PT. Raja Grafindo Persada.

Chaedar, A. A. (2002). Pokoknya kualitatif. dasar-dasar merancang dan melakukan penelitian kualitatif. Bandung: Pustaka Jaya.

Cleopatra, M. (2015). Pengaruh gaya hidup dan motivasi belajar terhadap prestasi belajar matematika. Formatif: Jurnal Ilmiah Pendidikan MIPA, 5(2).

Cramer, H., Sibbritt, D., Park, C. L., Adams, J., \& Lauche, R. (2017). Is the practice of yoga or meditation associated with a healthy lifestyle? Results of a national cross-sectional survey of 28,695 Australian women. Journal of psychosomatic research, 101, 104-109. https://doi.org/10.1016/j.jpsychores.2017.07.013

Dada, R., \& Tolahunase, M. (2018). Yoga Meditation Lifestyle Intervention: Impact on Male Reproductive Health. In Bioenvironmental Issues Affecting Men's Reproductive and Sexual Health (pp. 135-156). Academic Press. https://doi.org/10.1016/B978-0-12-801299-4.00009-8

Darmayasa, I., \& Sukra, G. (2013). Belajar Yoga Asanas Untuk Kesehatan Jasmani dan Rohani. Denpasar: Pt. Offset BP.

Davidow, W. H., \& Uttal, B. (1989). Total customer service: The ultimate weapon. HarperCollins.

Dewi, K. A. P., Mastryagung, G. A. D., \& Nurtini, N. M. (2017). Ersepsi Dan Sikap Mahasiswa Stikes Bali Tentang Yoga. Jurnal Kesehatan Terpadu, 1(2). 
Dinata, W. W. (2015). Menurunkan Tekanan Darah Pada Lansiamelalui Senam Yoga. JORPRES (Jurnal Olahraga Prestasi), 11(2).

Dittmann, K. A., \& Freedman, M. R. (2009). Body awareness, eating attitudes, and spiritual beliefs of women practicing yoga. Eating Disorders, 17(4), 273-292.

Echols, J. M., \& Shadily, H. (2019). Kamus inggris indonesia.

Elizabeth, R. (2007). Pemberdayaan wanita mendukung strategi gender mainstreaming dalam kebijakan pembangunan pertanian di perdesaan.

Esterberg, K. G. (2002). Qualitative methods in social research (No. 300.18 E8).

Fandhira, N. L., Maharani, M., \& Prihatningtyas, R. (2017). Pengaruh latihan hatha yoga terhadap tekanan intraokuler. Diponegoro medical journal (JURNAL KEDOKTERAN DIPONEGORO), 6(2), 975-982.

Garfinkel, M., \& Schumacher Jr, H. R. (2000). Yoga. Rheumatic Disease Clinics of North America, 26(1), $125-132$. https://doi.org/10.1016/S0889-857X(05)70126-5

Hamka, H. (2016). Kepemimpinan Perempuan dalam Era Modern. Al-Qalam, 19(1), 107-116.

Handayani, A. (2013). Keseimbangan kerja keluarga pada perempuan bekerja: Tinjauan teori border. Buletin Psikologi, 21(2), 90.

Hawari, D. (2013). Manajemen Stress Cemas dan Depresi, Penerbit FKUI.

Hendariningrum, R., \& Susilo, M. E. (2014). Fashion dan gaya hidup: identitas dan komunikasi. Jurnal Ilmu Komunikasi, 6(1), 25-32.

Herlyana, E. (2014). Fenomena coffee shop sebagai gejala gaya hidup baru kaum muda. THAQAFIYYAT: Jurnal Bahasa, Peradaban dan Informasi Islam, 13(1), 187-204.

Kaelan, M. S. (2005). Metode penelitian kualitatif bidang filsafat. Yogyakarta: Paradigma.

Kakigi, R., Nakata, H., Inui, K., Hiroe, N., Nagata, O., Honda, M., ... \& Kawakami, M. (2005). Intracerebral pain processing in a Yoga Master who claims not to feel pain during meditation. European Journal of Pain, 9(5), 581589. https://doi.org/10.1016/j.ejpain.2004.12.006

Kanserina, D., Haris, I. A., \& Nuridja, I. M. (2015). pengaruh literasi ekonomi dan gaya hidup terhadap perilaku konsumtif mahasiswa jurusan pendidikan ekonomi universitas pendidikan ganesha tahun 2015. Jurnal Pendidikan Ekonomi Undiksha, 5(1).

Khotimah, K. (2009). Diskriminasi gender terhadap perempuan dalam sektor pekerjaan. Yinyang: Jurnal Studi Islam Gender Dan Anak, 4(1), 158-180.

Kumar, S. S., \& Sumathi, U. (2017). Universalizing the concept of Avatarhood: Sri Aurobindo's discourse in comparing Krishna, Christ, and Buddha. International Journal of Linguistics, Literature and Culture, 3(2), 1-6. Retrieved from https://sloap.org/journals/index.php/ijllc/article/view/198

Laksono, S. S. (2012). Survei Tingkat Pemenuhan Kebutuhan Siswa-Siswi Kelas VIII SMP Kanisius Pakem Tahun Ajaran 2011/2012 Ditinjau Dari Teori Kebutuhan Maslow.

Lauche, R., Sibbritt, D., Ostermann, T., Fuller, N. R., Adams, J., \& Cramer, H. (2017). Associations between yoga/meditation use, body satisfaction, and weight management methods: Results of a national cross-sectional survey of 8009 Australian women. Nutrition, 34, 58-64. https://doi.org/10.1016/j.nut.2016.09.007

Miles, M. B., \& Huberman, A. M. (1992). Analisis data kualitatif.

Muhammad, H., \& Abdushomad, M. A. (2002). Dialog antara tasawuf dan psikologi: telaah atas pemikiran psikologi humanistik Abraham Maslow. Walisongo Press: Pustaka Pelajar.

Neumark-Sztainer, D., Watts, A. W., \& Rydell, S. (2018). Yoga and body image: How do young adults practicing yoga describe its impact on their body image?. Body image, 27, 156-168. https://doi.org/10.1016/j.bodyim.2018.09.001

Newcombe, S. (2007). Stretching for health and well-being: Yoga and women in Britain, 1960-1980. Asian medicine, 3(1), 37-63.

Nimtz, A. H. (2000). Marx and Engels: Their contribution to the democratic breakthrough. SUNY Press.

Paulson, S. (2008). "Beauty is more than skin deep." An ethnographic study of beauty therapists and older women. Journal of Aging Studies, 22(3), 256-265. https://doi.org/10.1016/j.jaging.2007.03.003

Piliang, Y. A. (2004). Semiotika teks: Sebuah pendekatan analisis teks. Mediator: Jurnal Komunikasi, 5(2), $189-198$.

Prabasmoro, A. P. (2004). Putih, Femininitas dan Seksualitas Perempuan dalam Iklan Kita. Jurnal Perempuan, Edisi, 37.

Putri, M. D., Fitriati, Y., Pramaningtyas, M. D., \& Hasibuan, D. H. S. (2022). Faktor-Faktor Yang Mempengaruhi Keikutsertaan Tes Inspeksi Visual Asetat Di Kulon Progo. Biomedika, 1-7.

Putri, O. N., \& Darwis, R. S. (2015). Pemberdayaan Perempuan Kepala Keluarga. Prosiding Penelitian Dan Pengabdian Kepada Masyarakat, 2(2). 
Rahima, S. (2006). Perempuan Bekerja, Dilema Tak Berujung. Diakses pada tanggal, 5.

Rahmaniyah, I. (2010). Pendidikan etika: Konsep jiwa dan etika perspektif Ibnu Miskawaih dalam kontribusinya di bidang pendidikan.

Saatcioglu, F. (2013). Regulation of gene expression by yoga, meditation and related practices: a review of recent studies. Asian journal of psychiatry, 6(1), 74-77. https://doi.org/10.1016/j.ajp.2012.10.002

Saskara, I. A. N., \& Maskie, G. (2012). Tinjauan perspektif ekonomi dan nonekonomi perempuan Bali yang bekerja di sektor publik: studi konflik peran. Jurnal Aplikasi Manajemen, 10(3), 542-552.

Sastropoetro, A. S. (1986). Partisipasi, komunikasi, persuasi dan disiplin dalam pembangunan nasional. Alumni.

Segara, I. N. Y. (2020). â€ œBade Berodaâ€: Transformasi dan Komodifikasi Budaya dalam Upacara Ngaben di Bali. Mudra Jurnal Seni Budaya, 35(1), 94-102.

Sengupta, P. (2012). Health impacts of yoga and pranayama: A state-of-the-art review. International journal of preventive medicine, $3(7), 444$.

Singer, I. W. (2015). Pendidikan Karakter Berlandaskan Tri Kaya Parisudha. Manikgeni.

Suamba, P. (2015). Yoga Sutra Patanjali Terjemahan Sanskerta-Indonesia. Denpasar: Widya Dharma Unhi.

Suda, I. K. (2017). Kastanisasi Pendidikan Ketika Pelajaran Agama Terpinggirkan.

Sudiarta, I. W. (2006). Rekonstruksi Visual Konsep-Konsep Kecantikan Tradisional Wanita Bali dan Manifestasinya di Dalam Kehidupan Masyarakat Bali Masa Kini (Doctoral dissertation, Tesis S2, Program Studi Kajian Budaya, Pasca Sarjana Universitas Udayana).

Susanto, A. S. (2013). Membuat Segmentasi Berdasarkan Life Style (Gaya Hidup). Jurnal Jibeka, 7(2), 1-6.

Telles, S., \& Desiraju, T. (1993). Automatic changes in Brahmakumaris Raja yoga meditation. International Journal of Psychophysiology, 15(2), 147-152. https://doi.org/10.1016/0167-8760(93)90072-W

Udayana, J. P. (2019). Kualitas hidup pascastrok peserta yoga pada Komunitas Ambarashram, Ubud, Bali. Jurnal Psikologi Udayana, 6(2), 347-356.

Wiasti, N. M. (2011). Perempuan Berpeluh yang Tak Mengeluh: Studi tentang Perempuan Pedagang Sayur di Pasar Baturiti, Tabanan, Bali.

Wirawan, I. G. B. (2018). Surya Namaskara benefits for physical health. International journal of social sciences and humanities, 2(1), 43-55.

Wirawan, I., Suda, I. K., Sukrawati, N. M., Paramartha, W., \& Suatama, I. B. (2020). Reducing Elderly Health Disorders through Laughing Yoga Therapy: Case Study in Badung Regency. Talent Development \& Excellence, 12(1).

You, T., \& Ogawa, E. F. (2020). Effects of meditation and mind-body exercise on brain-derived neurotrophic factor: a literature review of human experimental studies. Sports Medicine and Health Science, 2(1), 7-9. https://doi.org/10.1016/j.smhs.2020.03.001 